\title{
Intellectual Property Valuation Using Income Approach Method for Technology Licensing
}

\author{
Dhruv Joshi \\ Welingkar Institute of Management Development \& Research, Bangalore, India \\ dhruvmjoshi@gmail.com
}

\begin{abstract}
Technology licensing is one of the key transactions that enable translation of R\&D investments into profits by commercialization of technology. The elementary economics of such transaction suggests that while a licensor attempts to derive benefits greater than the cost of development of the technology protected by IPR, in exchange of monopoly rights, the licensee attempts to minimize the license value to ensure higher profits. This leads to the requirement of valuation of the technology by either party. This paper presents some of the key characteristics related to intellectual property valuation and an analysis of the income method approach in estimating the profitability of commercialization of a technology involving a patent.
\end{abstract}

Keywords: Income approach method, DCF analysis, technology commercialization, patent licensing, technology licensing

\section{Introduction}

"If this business were split up, I would give you the land and bricks and mortar, and I would take the brands and trademarks, and I would fare better than you."- John Stuart, Chairman of Quaker (ca. 1900). To put forth the idea expressed in the above quote in different words, it can be said that intellectual property is valuable and it exists in different forms within an organization. Catherine, Holland, Reed, Lee, Kimmel \& Peterson (2007) suggests that patents, copyrights, trademarks, industrial designs and trade secrets are some of the important forms of intellectual property. These are standardized form of intellectual property owned by an organization; however, according to Subhash and Vishakha (2010) there exists another set of similar valuable assets that enables smooth functioning of the organization, which includes client/customer information, the market share, brand loyalty, and the human capital. Collectively, these are referred as the intangible assets in a business enterprise.

\section{Literature Review}

These intangible assets are defined under Article 38 of the International Accounting Standards as " $A n$ identifiable non-monetary asset without physical substance. An asset is a resource that is controlled by the entity as a result of past events (for example, purchase or self-creation) and from which future economic benefits (inflows of cash or other assets) are expected." Based on this definition, an asset can be classified as an intangible asset if it exhibits the following three key characteristics:

- It should be an identifiable resource

- It should be controlled by an enterprise

- It should have economic importance

According to Manfred, Adolf, Ursula \& Karin (1999), since the patents, copyrights, trademarks are the assets that satisfy all the above criteria, they can be classified as intangible assets in a business enterprise. Weston, Donna \& Suchy (2005) suggests that valuation of intellectual property ("IP") may be viewed from several business perspectives. One such important motive is for transactional purpose, which is often reflected in mergers and acquisitions. The other contexts in which valuation is done are amortization for accounting purpose and calculating infringement damages or licensing the right to intellectual property.

Valuation of Intellectual Property: According to Timothy (2004), while valuing IP, there exists a set of differences as against valuation of a business enterprise. The following are some of the important differences that need to be considered while valuing intellectual property:

- The intellectual property represents only a part of the total business enterprise income, whereas the remaining portion of the business includes the financial assets, real estate and other fixed and current assets 
- A business is said to grow in perpetuity, while the IP has a specific, which is the Remaining Useful Life (RUL)

- Also, within the RUL, the economic life of the IP may be different from that of the RUL due to technology obsolescence

Based on these critical differences, one may infer that investments in IP are relatively more risky than an investment in a business enterprise. An argument in this respect can be - a business enterprise may be viewed as a diversified portfolio, which consists of variety of assets - land, building, machinery, investments and advances, etc., while on the other hand, IP protects a specific technology in form of patents, or a specific brand or a set of brands in form of a trademark and hence the economic performance depends solely on the success of the technology or the brand. The increased inherent risk in this asset - intellectual property, is reflected in the discounting rate used in the valuation as seen in the subsequent sections of this paper.

However, there are also certain similarities in business enterprise valuation and intellectual property valuation. According to Richard (2009), qualitative analysis and assessment of the industrial sector in which a business enterprise operates, the R\&D performed by the industry, or the industrial domain to which the technology caters is important. This, I believe, sets the tone for valuation as it portrays the potential strength of the business environment for the term for which the future cash flows are estimated. In addition, it is suggestive of the skills and the expertise a firm holds to capitalize or commercialize on its business decisions successfully in the market or enhance the technological innovation to the next level. James, McGuigan, Charles, Frederick \& deB (2007) emphasizes on Porter's 5 Forces Model as one of the tools for assessing industry-level parameters. Warren (2010) details on the VRIO Framework that assesses the firm's own strengths and weakness that can be compared against the industry benchmarks. Edith, Edith \& Christos (2009) in the book - The Theory of Growth of Firms, and Christos (2009) in his publication - Edith Penrose's 'The Theory of the Growth of the Firm' Fifty Years Later describes the importance of the management of the firm in driving the firm towards growth. All these frameworks form a part of the qualitative analysis in addition to the SWOT or PEST analysis as detailed by Ross (2002).

As a part of the next stage of analysis, as stated by Pamela (2004), the economic life of the product or process protected by the patent shall be estimated. For instance, according to the TRIPS Agreement, under article 33 of the agreement, in legal terms, the term of patent is 20 years from the date of application. However, the development in the domain may outpace the performance of the protected technology. An observation in this respect can be software industry where the product life cycle is short compared to pharmaceutical industry where a block-buster drug continues to hold strong (e.g. Pfizer's Lipitor) for a majority of the term of the patent. According to basic economics, the key parameters in determining the economic life are the anticipated demand-supply, the pricing pressures, and the key regulations that influence the market of the product or the service. A majority of such parameters can be described in form of the elasticity of demand. Richard (2009) refers to the cross elasticity of demand that essentially determines the strength that IP provides to a product in the market in view of the competitive products. Jeffrey (2005) emphasizes on price elasticity of demand as another tool for valuation purposes. Thus, it is important to characterize valuation term based on the economic life of the product or a service instead of the RUL of the IP protection.

\section{Figure 1: Approach to Valuation - Pre-Valuation Stages}

Complied by the Researcher

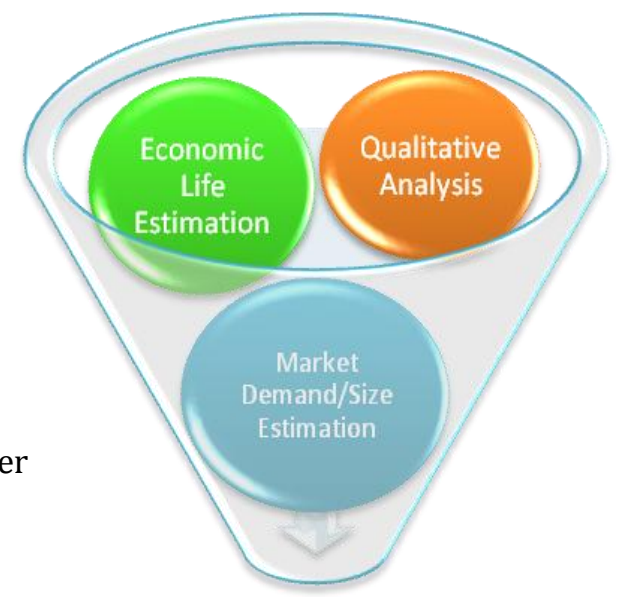


Once the three parameters in the above funnel diagram presents a positive picture for commercialization, the valuation toolbox is used.

Valuation Toolbox: The valuation toolbox consists of major four methods of valuation which are:

- The Cost Method

- The Income Method

- The Market Method

- The Real Options Valuation Method

The cost method involves summation of the costs incurred in developing the technology and the amount spent on protection of through intellectual property. Referring to Norman (2005), the cost method can avail benefit of indexation of costs. However, this method does not take into consideration the benefit beyond the cost that can be derived from the market conditions. Thus, it may form the base line of valuation. On the other hand, as stated by Robert (1997), the income method involves a thorough estimation of market parameters to forecast the future cash flows to estimate the economic benefit that can be derived by commercialization of technology. However, it has several components that are difficult to predict over a longer duration.

Another quantitative approach as stated by Spruson \& Ferguson (2007) is the market method and is sometimes referred as comparable transactions/price method. It is more of a reflection of market trend rather than the inherent potential of the technology itself. It can be used to confirm the value of an asset derived using other valuation methods. Oliver (2006) highlights the Real Options Valuation ("ROV") method as an advanced technique that incorporates managerial flexibility in the valuation toolbox, which is absent in case of the income method or the NPV method of valuation. A comparative overview of the valuation techniques is presented in exhibit 1 of this paper. The case presented in this paper deals with the income approach method for valuing the project profitability.

\section{Case Details}

Cool Materials Inc. ("Cool Materials") is a research firm in the material science domain and holds a patent on a new type of material, which can be used in cooling applications. Qualitatively, Home Solutions Inc. ("HSI"), a publicly listed conglomerate, believes that the newly developed material has a huge potential in the cryogenic and refrigeration markets. To assess the commercial benefit of this new material, the only data that HSI managers have is the pricing and demand data provided by a market research team for the past six years in the same space. HSI believes the current levels of penetration and the geographical reach of the product is too low and has the potential to increase 3-4 folds globally by the end of the term of the patent. In addition, the product being protected by patent offers significant economic benefit to the owner. The past record for six years reflects that while the CAGR of growth of demand was $24.64 \%$, the corresponding price decrease was $4.16 \%$ per annum. HSI managers believe that this quick expanding market with relatively insignificant price reduction created an elastic demand of the product and hence, despite downward pressure on the pricing, the expanding market shall enable greater revenues and thus it presents an opportunity to license the patented technology.

HSI managers are concerned that during the term of the patent till 2029, the pricing pressures shall continue due to competition from other similar products and further product development and research, but are $90 \%$ confident that prices shall not fall below $\$ 30 / \mathrm{kg}$ from the current levels of $\$ 77.5 / \mathrm{kg}$. Thus, HSI managers believe that all through the term of the patent, the price is likely to remain in the range $\$ 30$ 70 per $\mathrm{kg}$. HSI managers also believe that their margins may be squeezed if the prices fall below $\$ 30$ per $\mathrm{kg}$ that may eventually lead HSI opting out of manufacturing and marketing the product. Another concern is the expanding market, which would eventually slow down with increasing penetration each year. To commercialize the technology, Cool Materials intends to transfer its patent rights to HSI for a one-time payment of $\$ 85$ million. In addition to this, HSI has to spend additional amount on installation of plant and machinery to manufacture and market the material. Additional costs on marketing and sales shall be incurred by HSI to derive the expected commercial benefits. The HSI managers are confronted with yet another question of the term of license in view of the pricing pressure and the anticipated slow down in the growth of the market. The managers also need to assess the profitability of the project, if Cool Materials successfully assigned the license (patent rights).

The HSI managers have the data presented in Table 1 to estimate the term of the license and the profitability of the project. Table 2 presents the business sectors where HSI has a presence. The : Table 15 
provides the financial details of the Specialty Materials SBU; Error! Reference source not found. provides the cost structure of the SBU and Error! Reference source not found. provide for the statistical details pertaining to each of the stated costs. : Table 15 and Error! Reference source not found. detail on the other additional estimated costs and the cost scenarios for the forecasting period respectively. With this limited data, the HSI managers have to estimate the market demand data and the corresponding average price each year and hence the anticipated revenue from the licensed technology. Based on this analysis, the HSI managers shall forecast the FCF to the firm to estimate the NPV of the project.

Table 1: Data from Market Research Team

\begin{tabular}{cccr}
\hline Duration & Year & Demand (MT) & Avg. Annual Price (\$/MT) \\
\hline 1 & 2005 & 1000 & 100000.00 \\
2 & 2006 & 1550 & 95000.00 \\
3 & 2007 & 2100 & 92500.00 \\
4 & 2008 & 2750 & 87000.00 \\
5 & 2009 & 3400 & 80000.00 \\
6 & 2010 & 3750 & 77500.00 \\
\hline
\end{tabular}

Table 2: Business Sectors of Presence of HIS and Revenue Overview, Representative figures adopted from Honeywell Inc.'s 10-K filing for year ending December 31, 2010

\begin{tabular}{lcccc}
\hline Business Unit & $\mathbf{2 0 1 0}$ & $\mathbf{2 0 0 9}$ & $\mathbf{2 0 0 8}$ & Average \\
\hline Aerospace & $32.01 \%$ & $34.82 \%$ & $34.60 \%$ & $33.81 \%$ \\
Automation Control and Systems & $41.20 \%$ & $40.80 \%$ & $38.35 \%$ & $40.12 \%$ \\
Specialty Materials & $14.16 \%$ & $13.41 \%$ & $14.41 \%$ & $13.99 \%$ \\
Transportation Systems & $12.62 \%$ & $10.96 \%$ & $12.64 \%$ & $12.08 \%$ \\
\hline
\end{tabular}

Table 3: Specialty Materials Financial Details, Representative figures adopted from Honeywell Inc.'s 10-K filing for year ending December 31, 2010

\begin{tabular}{|c|c|c|c|}
\hline Year/Details (in Million USD) & 2010 & 2009 & 2008 \\
\hline Net Sales & 4,726 & 4,144 & 5,266 \\
\hline COGS & 3,554 & 3,127 & 4,121 \\
\hline SD\&A & 345 & 345 & 395 \\
\hline Other Expenses & 78 & 67 & 29 \\
\hline Segment Profit & 749 & 605 & 721 \\
\hline
\end{tabular}

Table 4: Specialty Materials SBU - Cost Structure Details

\begin{tabular}{lccc}
\hline \% Based on Total Revenue (Sales) & & & \\
\hline Net Sales & $100.00 \%$ & $100.00 \%$ & $100.00 \%$ \\
COGS & $75.20 \%$ & $75.46 \%$ & $78.26 \%$ \\
SD\&A & $7.30 \%$ & $8.33 \%$ & $7.50 \%$ \\
Other Expenses & $1.65 \%$ & $1.62 \%$ & $0.55 \%$ \\
Segment Profit & $15.85 \%$ & $14.60 \%$ & $13.69 \%$ \\
\hline
\end{tabular}

Table 5: Specialty Materials SBU - Statistical Details

\begin{tabular}{lccc}
\hline Statistical Details - Specialty Materials & COGS & SD\&A & Other Expenses \\
\hline Average & $76.31 \%$ & $7.71 \%$ & $0.63 \%$ \\
Std. Dev. & $1.69 \%$ & $0.54 \%$ & $0.63 \%$ \\
Upper Limit & $79.70 \%$ & $8.80 \%$ & $1.88 \%$ \\
Lower Limit & $72.92 \%$ & $6.62 \%$ & $-0.63 \%$ \\
\hline
\end{tabular}


Table 6: Additional Estimated Costs and Parameters for Valuation

\begin{tabular}{|c|c|c|c|c|c|c|}
\hline Cost/Year & 2011 & 2012 & 2013 & 2014 & 2015 & 2016 \\
\hline $\begin{array}{l}\text { Marketing Costs } \\
\text { and Sales Force } \\
\text { Development* }\end{array}$ & 20.00 & 15.00 & 15.00 & 9.00 & 5.00 & 2.00 \\
\hline \multicolumn{7}{|c|}{$\begin{array}{l}\text { *Beyond } 2016 \text {, these costs are estimated to be } \$ 1 \text { million inclusive of the costs incurred in } \\
\text { globally }\end{array}$} \\
\hline Capital & \multirow{2}{*}{\multicolumn{6}{|c|}{$\begin{array}{l}3.78 \% \# \text { of the revenue each year, except for the last two years of the term of the } \\
\text { license } \\
\text { \# Based on the Capital Expenditure: Revenue Ratio for past three years for the } \\
\text { Specialty Materials SBU }\end{array}$}} \\
\hline Expenditure & & & & & & \\
\hline Working Capital & \multicolumn{6}{|c|}{$\begin{array}{l}10 \% \text { of the Incremental Revenue (except for } 2011 \text { where is it assumed to be } \\
\text { same as increase in working capital in year 2012) }\end{array}$} \\
\hline Taxes & \multicolumn{6}{|l|}{$35 \%$} \\
\hline Depreciation & \multicolumn{6}{|l|}{$4 \%$ of $\mathrm{COGS}$} \\
\hline
\end{tabular}

Approx. Scrap Value at the End of the Project: 2 Million

Table 7: The Cost Scenarios for the Forecasting Period

\begin{tabular}{lc}
\hline Scenario & Probability \\
\hline Optimistic & $10 \%$ \\
Most Likely (Expected) & $35 \%$ \\
Pessimistic & $55 \%$ \\
Total & $100 \%$ \\
\hline
\end{tabular}

Estimation of Demand and Price: The demand for the specialty material is assumed function of time since no other data on the market share is available. Based on the trend for the past six years, the HSI managers believe that similar trend shall continue until the term of the patent with the expanding market and increasing penetration. The demand is estimated using single variable regression technique presented in Table 1. Thus, assuming a linear relationship between the demand and time, the demand through the years 2011 until 2029 is estimated. Alternatively, using MS Excel, the same can be estimated using the TREND function.

\section{Summary of Single Variable Regression Analysis}

$\mathrm{R}^{2}=0.9975, \mathrm{~F}(1,10)=30.78, \mathrm{p}<0.01, \beta=570$, Demand Forecast Equation: $\mathrm{Y}=\alpha+(\beta *$ Duration $)$

Demand $=430+($ Duration $* 570)$

The forecasted data then needs to be verified against the assumption of slowing of the growth of demand with the years passing by. Based on the data presented in Table 1, the geometric mean growth rate for demand is $27.13 \%$. In the forecasted demand, the growth rate of demand falls from $17.87 \%$ in 2011 to approximately $4 \%$ in 2029, the last year of the legal term of the patent. Thus, the forecasted demand does not violate the assumption of slower growth rate as anticipated by the HSI managers. The estimation of demand is a vital step in evaluating the technology potential as in the next step it enables estimation of price. : Table 15 presents the forecasted demand data using the above-referred equation: 
Table 8: Forecasted Demand Data

\begin{tabular}{cr}
\hline Year & Demand (MT) \\
\hline 2011 & 4420 \\
2012 & 4990 \\
2013 & 5560 \\
2014 & 6130 \\
2015 & 6700 \\
2016 & 7270 \\
2017 & 7840 \\
2018 & 8410 \\
2019 & 8980 \\
2020 & 9550 \\
2021 & 10120 \\
2022 & 10690 \\
2023 & 11260 \\
2024 & 11830 \\
2025 & 12400 \\
2026 & 12970 \\
2027 & 13540 \\
2028 & 14110 \\
2029 & 14680 \\
\hline
\end{tabular}

Estimation of Price: The price of the material as a variable reflects a specific trend with respect to two other variables:

a) Time (Years)

b) Demand

However, unlike pharmaceutical products which defies the law of demand being a necessity, the specialty material is assumed to follow the law of demand and hence, it can be assumed that the demand of the material is a better indicator of the price of the product compared to the pricing trend (based on timeline) provided by the market research team. Assuming the law of demand holds true for the specialty material, based on the graphical plot of Price v. Demand for the historical data, the relationship between the price and the demand can be expressed by the following equation: Price $(y)=-8.1776^{*}$ Demand +108497 However, with this equation, the forecasted price is negative for the last three years of the patent term and it violates the assumption of the HSI managers that, with $90 \%$ confidence limit, the prices shall not fall below $\$ 30$ per kg any time during the term of the patent. Thus, the price distribution reflected by the above-referred equation does not hold true. Since the price of the specialty product cannot be negative, it can be assumed that the price is log-normally distributed. Thus, a plot of natural log of the price against the historical demand shall reflect the true pricing distribution of the specialty product. : Table 15 provides the details on the demand and natural log of the price for the data presented in Table 1, while Figure 2 presents a graphical plot of natural log of price versus the demand data.

Table 9: Price-Demand Relationship

\begin{tabular}{crrr}
\hline Year & Demand (MT) & Price (\$/MT) & Ln (Price) \\
\hline 2005 & 1000 & 100000 & 11.5129 \\
2006 & 1550 & 95000 & 11.4616 \\
2007 & 2100 & 92500 & 11.4350 \\
2008 & 2750 & 87000 & 11.3737 \\
2009 & 3400 & 80000 & 11.2898 \\
2010 & 3750 & 77500 & 11.2580 \\
\hline
\end{tabular}


Figure 2: Price Demand Relationship

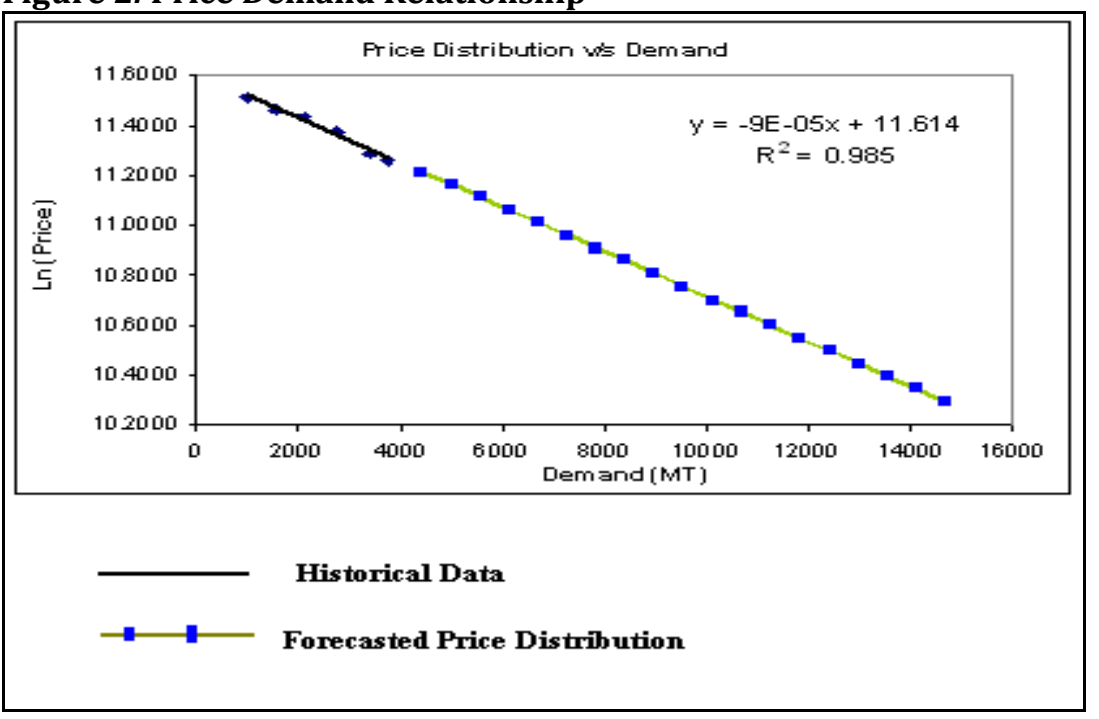

Complied by the Researcher

Based on the equation presented in

Figure 2: Table 15 presents the anticipated price for forecasting. The presents the non-linear relationship between the anticipated price and the forecasted demand.

Table 10: Anticipated Price for Forecasting

\begin{tabular}{rrrr}
\hline Year & Demand (MT) & Ln(Price)-Forecasted & Price=Exp(Ln(Price)) \\
\hline 2011 & 4420 & 11.2162 & $\$ 74,324.80$ \\
2012 & 4990 & 11.1649 & $\$ 70,608.09$ \\
2013 & 5560 & 11.1136 & $\$ 67,077.24$ \\
2014 & 6130 & 11.0623 & $\$ 63,722.95$ \\
2015 & 6700 & 11.0110 & $\$ 60,536.39$ \\
2016 & 7270 & 10.9597 & $\$ 57,509.19$ \\
2017 & 7840 & 10.9084 & $\$ 54,633.36$ \\
2018 & 8410 & 10.8571 & $\$ 51,901.35$ \\
2019 & 8980 & 10.8058 & $\$ 49,305.95$ \\
2020 & 9550 & 10.7545 & $\$ 46,840.34$ \\
2021 & 10120 & 10.7032 & $\$ 44,498.02$ \\
2022 & 10690 & 10.6519 & $\$ 42,272.84$ \\
2023 & 11260 & 10.6006 & $\$ 40,158.93$ \\
2024 & 11830 & 10.5493 & $\$ 38,150.72$ \\
2025 & 12400 & 10.4980 & $\$ 36,242.94$ \\
2026 & 12970 & 10.4467 & $\$ 34,430.57$ \\
2027 & 13540 & 10.3954 & $\$ 32,708.82$ \\
2028 & 14110 & 10.3441 & $\$ 31,073.17$ \\
2029 & 14680 & 10.2928 & $\$ 29,519.31$ \\
\hline
\end{tabular}


Figure 3: Non-Linear Price-Demand Relationship

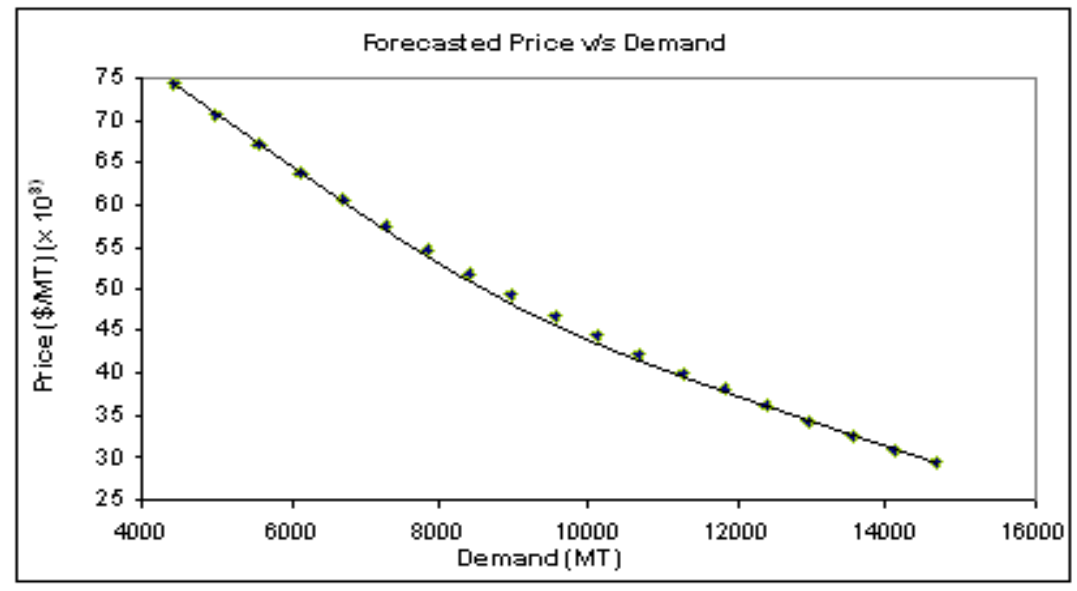

Complied by the Researcher

Revenue and License Term Estimation: Based on the forecasted demand and the pricing for each year during the patent term, the revenue is calculated using common formula:

Total Revenue $=$ Forecasted Demand X Anticipated Price Based on the above referred two parameters the forecasted demand and the average annual price, the revenue reflects curve similar to an inverted Ushape. The transition from the year 2023 to 2024 reflects expanding market, but on the other hand provides sufficient time for development of similar or enhanced product materials that would create a downward pressure on the pricing of the specialty material. This transition also reflects the change in the elasticity of demand from elastic zone to inelastic and hence results in drop in revenues (as seen in Figure 4 and Figure 5). Thus, the patent term may continue to exist until 2029, subject to renewal, however, the economic life the invention, as of today, seems only until 2023.

\section{Figure 4: Forecasted Project Revenues}

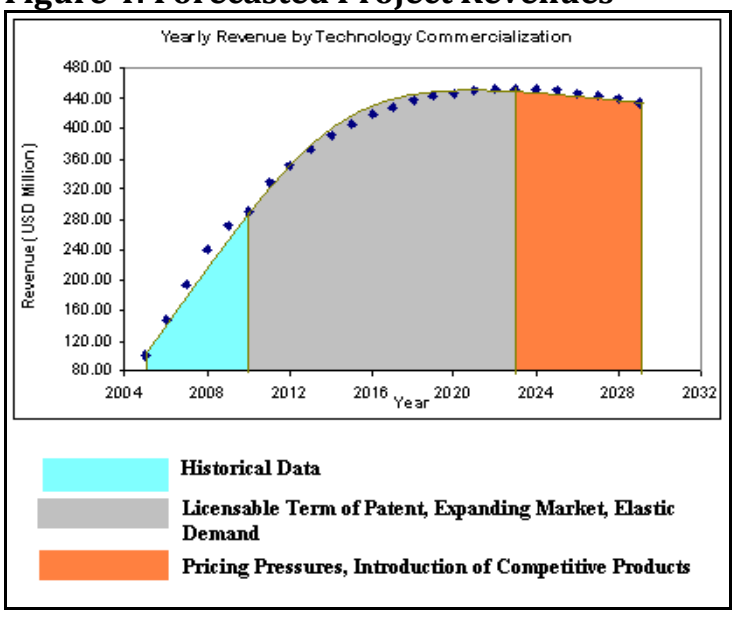

Complied by the Researcher
Figure 5: Price Elasticity of Demand of Product

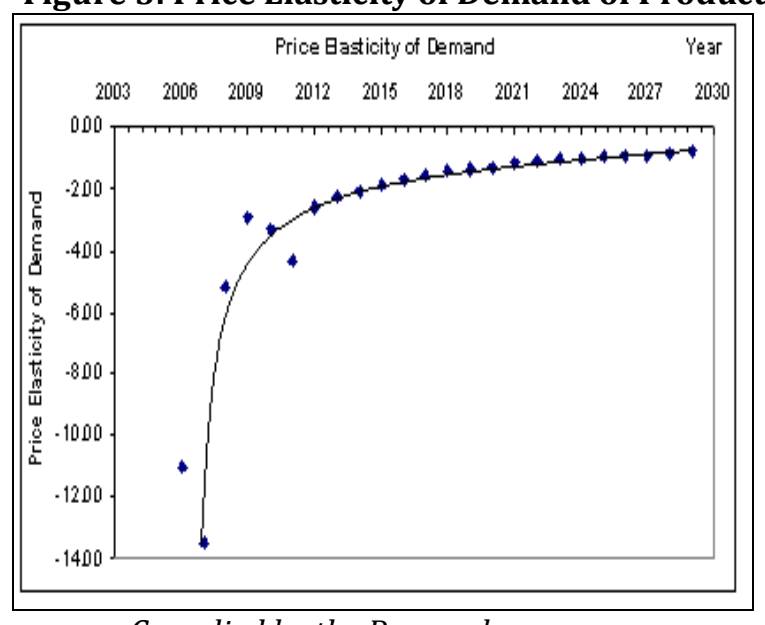

Complied by the Researcher

In such an event, under the clause of the term and termination of the IP license agreement, HSI and Cool Materials may pin-down clause of extending the term of contract beyond 2023 based on the terms and conditions acceptable to each of the parties. Such provision may help HSI in extending the term of the contract beyond 2023 if the economic and market conditions then favor continued business participation.

Estimation of Free Cash Flows from the Project: To estimate the free cash flows from the project, besides forecasted revenues in the above section, the costs are an important parameter. The costs involve majorly two types of costs:

a) The Cost of Goods Sold (COGS), which accounts for the operating expenditures related to the product

b) The Selling, Distribution and Administration expenses (SD\&A) which reflect the marketing and other administrative costs. HSI managers believe that referring to the COGS and SD\&A in the P\&L of the conglomerate, as a whole would not reflect the true costs associated with manufacturing of the product. 
Instead, the specialty material SBU specific historical data shall enable better estimation of the costs. The statistical analysis of the SBU has been referred in Table 4. Thus, the mean and the standard deviation of these costs associated with the specialty materials SBU of HSI shall be used to simulate the costs. The Mean + Std. Dev., Mean, and Mean - Std. Dev. are used to estimate NPV under the pessimistic, most likely, and optimistic scenario respectively.

Estimation of the Discounting Rate: As referred earlier, a business enterprise may be viewed as a diversified portfolio comprising assets in form of land, plant and machinery and the inventory. On the other hand, in addition to opportunity cost, the licensing technology entails following risks:

- Risk due to obsolescence of technology during the license term

- The market risk

- Risk due to weak IPR that may allow imitating company to enter the market without having to pay the penalty

- Company specific risk - despite all the favorable circumstances, the company may not be able to successfully commercialize the technology

- We define all these risks on a Likert Scale and then with an empirical formula, these can be quantified to obtain a discounting rate.

For instance, in this case, the Likert Scale ranges from 1 to 7 , where 1 represents least risk and 7 represents maximum risk. This rating has a direct impact on the risk rate as the empirical formula takes into account the numerical rating for the specific risk to calculate the risk component. The typical percentage values for each value on the Likert Scale are presented in

Table 11. In order to translate the qualitative aspect of the risk into quantitative, each risk parameter is assigned a weight-age based on the perception of the management of each form of risk.

Table 12 details on risk quantification, where the average risk is the average of the lower and upper range stated in

Table 11.

Table 11: Discounting Rate- Quantification of Risk

\begin{tabular}{clcc}
\hline Likert Scale & \multicolumn{1}{c}{ Description } & Lower Range & Upper Range \\
\hline 1 & Risk-free & $8.00 \%$ & $18.00 \%$ \\
2 & Very Low Risk & $15.00 \%$ & $20.00 \%$ \\
3 & Low Risk & $20.00 \%$ & $30.00 \%$ \\
4 & Moderate Risk & $25.00 \%$ & $35.00 \%$ \\
5 & High Risk & $30.00 \%$ & $40.00 \%$ \\
6 & Very High Risk & $35.00 \%$ & $45.00 \%$ \\
7 & Extremely High Risk & $50.00 \%$ & $80.00 \%$ \\
\hline
\end{tabular}

Source: Dr. Richard Razgaitis, Valuation and Dealmaking of Technology-Based Intellectual Property, John Wiley and Sons, Chapter VII, Exhibit 7.7, Pg. 271

Table 12: Weightage Based Quantification of Risk

\begin{tabular}{clccc}
\hline Weight-age & Risk & Rating & Average Risk \% & Quantified Risk \\
\hline 50 & Corporate RAHR & - & $18.00 \%$ & $9.00 \%$ \\
15 & Technology & 5 & $35.00 \%$ & $5.25 \%$ \\
10 & Market & 4 & $30.00 \%$ & $3.00 \%$ \\
15 & IP Rights & 3 & $25.00 \%$ & $3.75 \%$ \\
10 & Honeywell & 2 & $17.50 \%$ & $1.75 \%$ \\
Total Quantified Risk & & & $22.75 \%$ \\
\hline
\end{tabular}

Determination of NPV:

- The revenue or the turnover is estimated based on the forecasted demand and the estimate of the average annual price 
- For COGS and SD\&A, which are likely to have variations, the Mean + Std. Dev., Mean, and Mean Std. Dev. are used to estimate NPV under the pessimistic, most likely and optimistic scenario involving these costs. The other expenses referred in Table 3 are replaced with marketing and sales forces construction cost presented in Table 6

- The capital expenditure budget is as per the information provided in Table 6

- The depreciation is assumed $4 \%$ of the COGS for the given year, whereas the increase in working capital is assumed $10 \%$ of the incremental revenue, except for the year 2011 where is it assumed same as year 2012

- The tax rate is assumed equivalent to corporation tax rate at $35 \%$

- The discounting rate is taken as calculated in

- Table 12

Table 13: Estimation of NPV under Most Likely Scenario

\begin{tabular}{|c|c|c|c|c|c|c|c|c|c|c|c|c|c|c|c|c|c|c|c|c|}
\hline ָ̃ & 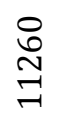 & $\begin{array}{l}\text { on } \\
\text { Ln } \\
\stackrel{2}{\circ}\end{array}$ & 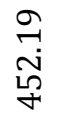 & $\begin{array}{l}\text { பி } \\
\text { மे } \\
\text { ஸे }\end{array}$ & $\begin{array}{l}\infty \\
\infty \\
\dot{m}\end{array}$ & $\stackrel{\text { ¿ }}{\circ}$ & 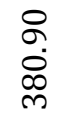 & $\stackrel{\overbrace{}}{ָ}$ & $\begin{array}{l}\infty \\
\infty \\
\stackrel{M}{\sim}\end{array}$ & స్. & 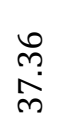 & $\begin{array}{l}\stackrel{b}{m} \\
\stackrel{n}{m}\end{array}$ & 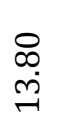 & $\begin{array}{l}8 \\
\circ \\
0\end{array}$ & $\begin{array}{l}\text { Oे } \\
\ddot{0}\end{array}$ & $\underset{\text { ¿ }}{\stackrel{\text { in }}{ }}$ & $\stackrel{+}{\stackrel{+}{n}}$ & $\hat{\circ}$ & $\begin{array}{l}\stackrel{R}{m} \\
\dot{m}\end{array}$ & \\
\hline $\begin{array}{l}\tilde{N} \\
\text { Vे }\end{array}$ & $\begin{array}{l}\stackrel{\circ}{\circ} \\
\text { ○ } \\
\stackrel{-}{1}\end{array}$ & $\underset{\underset{\sim}{N}}{\stackrel{N}{N}}$ & $\begin{array}{l}8 \\
\stackrel{-}{1} \\
\stackrel{\text { ㅇ }}{+}\end{array}$ & $\begin{array}{l}\stackrel{0}{\infty} \\
\stackrel{+}{+} \\
\stackrel{m}{2}\end{array}$ & $\begin{array}{l}\dot{\infty} \\
\dot{m}\end{array}$ & $\stackrel{8}{\circ}$ & $\begin{array}{l}\stackrel{0}{0} \\
\stackrel{0}{0} \\
\infty \\
m\end{array}$ & $\stackrel{\stackrel{H}{N}}{i}$ & $\begin{array}{l}\stackrel{a}{\hat{n}} \\
\stackrel{m}{n}\end{array}$ & ㄱ.? & mे & ले & $\begin{array}{l}\stackrel{2}{\hat{r}} \\
\text { m } \\
\vec{r}\end{array}$ & $\begin{array}{l}\circ \\
0\end{array}$ & $\stackrel{0}{\stackrel{0}{0}}$ & & $\begin{array}{l}\infty \\
\stackrel{2}{0} \\
\text { in }\end{array}$ & o̊ & $\begin{array}{l}\text { m} \\
\text { r }\end{array}$ & \\
\hline $\begin{array}{c}\vec{N} \\
\stackrel{N}{N}\end{array}$ & $\begin{array}{l}\stackrel{ }{N} \\
\stackrel{-}{\circ}\end{array}$ & \begin{tabular}{l} 
o̊ \\
$\stackrel{g}{+}$ \\
\multirow{J}{*}{}
\end{tabular} & $\begin{array}{l}\text { m̃ } \\
\text { ○े } \\
\text { 요 }\end{array}$ & $\begin{array}{l}\text { Uै } \\
\text { mे } \\
\stackrel{m}{+}\end{array}$ & $\begin{array}{l}\vec{N} \\
\dot{m}\end{array}$ & $\underset{-}{\stackrel{-}{\circ}}$ & $\begin{array}{l}m \\
\text { m. } \\
\stackrel{\text { }}{m}\end{array}$ & $\begin{array}{l}\text { مे } \\
\stackrel{1}{0}\end{array}$ & $\begin{array}{l}\vec{\nabla} \\
\stackrel{\sim}{\sim}\end{array}$ & $\begin{array}{l}m \\
\stackrel{0}{0} \\
\text { N }\end{array}$ & $\stackrel{\vec{N}}{\stackrel{n}{m}}$ & $\stackrel{\vec{N}}{\stackrel{n}{n}}$ & $\begin{array}{l}\vec{\nabla} \\
\text { mे }\end{array}$ & $\begin{array}{l}\text { ô } \\
\text { İ }\end{array}$ & ஜे & & $\begin{array}{l}\text { ⿹े } \\
\text { mे } \\
m\end{array}$ & $\stackrel{0}{\stackrel{0}{0}}$ & $\begin{array}{l}\text { Iొ } \\
\text { ஸे }\end{array}$ & \\
\hline $\begin{array}{l}\text { ָे } \\
\text { N } \\
\text {. }\end{array}$ & $\begin{array}{l}\text { 옹 } \\
\text { 음 }\end{array}$ & 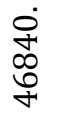 & $\begin{array}{l}\underset{m}{m} \\
\stackrel{f}{+}\end{array}$ & $\begin{array}{l}m \\
\stackrel{m}{+} \\
\stackrel{m}{+}\end{array}$ & $\begin{array}{l}\stackrel{\infty}{+} \\
\stackrel{m}{m}\end{array}$ & $\underset{-}{\stackrel{-}{\circ}}$ & 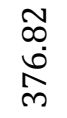 & 농 & $\begin{array}{l}\qquad 0 \\
\stackrel{0}{0} \\
\stackrel{\sim}{\sim}\end{array}$ & $\begin{array}{l}\text { ळ. } \\
\text { హ. }\end{array}$ & $\begin{array}{l}\text { o. } \\
\text { bे }\end{array}$ & 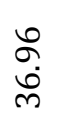 & $\begin{array}{l}\stackrel{L}{0} \\
\stackrel{m}{\rightarrow}\end{array}$ & बु. & \begin{tabular}{l}
0 \\
\multirow{0}{0}{}
\end{tabular} & & 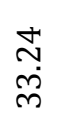 & $\stackrel{m}{\stackrel{0}{0}}$ & 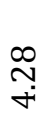 & \\
\hline $\begin{array}{l}0 \\
\stackrel{2}{2} \\
\text { N }\end{array}$ & $\begin{array}{l}\infty \\
\infty \\
\infty \\
\infty\end{array}$ & 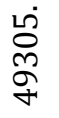 & 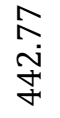 & $\begin{array}{l}\infty \\
\infty \\
\text { m} \\
m\end{array}$ & $\stackrel{m}{\stackrel{m}{m}}$ & نه & $\begin{array}{l}\stackrel{\sigma}{\sigma} \\
\underset{n}{N}\end{array}$ & $\begin{array}{l}\stackrel{\infty}{\hat{\sigma}} \\
\stackrel{\sigma}{\sigma}\end{array}$ & $\begin{array}{l}\vec{n} \\
\text { ஸे }\end{array}$ & $\begin{array}{l}\sigma \\
\sigma \\
\sigma \\
-1\end{array}$ & $\begin{array}{l}\text { ĥ } \\
\text { n̊ }\end{array}$ & 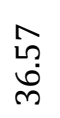 & $\begin{array}{l}\vec{n} \\
\stackrel{n}{\sim}\end{array}$ & $\underset{\sigma}{\stackrel{+}{0}}$ & $\begin{array}{l}\tilde{0} \\
0\end{array}$ & & 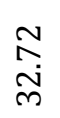 & $\begin{array}{l}0 \\
\stackrel{1}{0}\end{array}$ & 군. & \\
\hline $\begin{array}{l}\infty \\
\stackrel{1}{2} \\
\text { N }\end{array}$ & 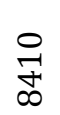 & 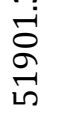 & 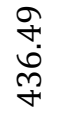 & $\begin{array}{l}\text { oे } \\
\text { m} \\
\text { m}\end{array}$ & $\begin{array}{l}\qquad 0 \\
\stackrel{1}{0} \\
m\end{array}$ & $\underset{\sim}{\stackrel{\text { }}{8}}$ & $\begin{array}{r}\hat{N} \\
\hat{n}\end{array}$ & $\begin{array}{l}\infty \\
\stackrel{\infty}{\wedge} \\
\infty \\
0\end{array}$ & $\begin{array}{l}\tilde{m} \\
\stackrel{\sim}{\sim}\end{array}$ & $\begin{array}{l}\underset{+}{+} \\
\stackrel{7}{7}\end{array}$ & $\begin{array}{l}\text { L } \\
\text { j. } \\
\text { m }\end{array}$ & $\begin{array}{l}\text { L } \\
0 \\
\dot{0}\end{array}$ & $\begin{array}{l}\tilde{m} \\
\stackrel{\oplus}{\sim}\end{array}$ & 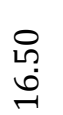 & $\begin{array}{c}N \\
\infty \\
0\end{array}$ & & $\begin{array}{l}\text { L } \\
\text { ते } \\
m\end{array}$ & $\stackrel{\sigma}{\overrightarrow{1}}$ & 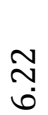 & \\
\hline م્ & 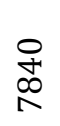 & $\begin{array}{l}\text { mె } \\
\text { Hे }\end{array}$ & 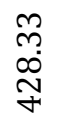 & 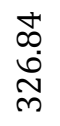 & $\begin{array}{l}\tilde{O} \\
\dot{m} \\
\dot{m}\end{array}$ & $\stackrel{\text { ¿े }}{\circ}$ & 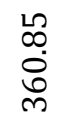 & $\begin{array}{l}f \\
\text { î }\end{array}$ & $\begin{array}{l}\hat{O} \\
\stackrel{m}{\sim}\end{array}$ & $\begin{array}{l}\dot{\sigma} \\
\stackrel{\sigma}{\sigma}\end{array}$ & $\begin{array}{l}\text { m. } \\
\text { Ln } \\
\text { nे }\end{array}$ & $\begin{array}{l}\text { mे } \\
\text { Ln }\end{array}$ & $\begin{array}{l}\hat{O} \\
\stackrel{M}{\rightarrow}\end{array}$ & ने & $\begin{array}{c}\text { Oै } \\
\text { - }\end{array}$ & & $\frac{N}{\bar{m}}$ & 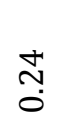 & $\stackrel{m}{\stackrel{\sim}{r}}$ & \\
\hline 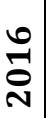 & $\stackrel{尺}{N}$ & 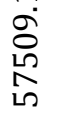 & $\begin{array}{l}\text { oे } \\
\infty \\
\stackrel{+}{+}\end{array}$ & $\begin{array}{l}m \\
0 \\
\stackrel{a}{ } \\
\vec{m}\end{array}$ & $\underset{\sim}{\stackrel{m}{N}}$ & $\begin{array}{l}\stackrel{8}{ } \\
\text { in }\end{array}$ & $\begin{array}{l}\stackrel{b}{N} \\
\text { m̃ } \\
\text { Dn } \\
\text { m }\end{array}$ & 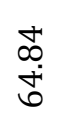 & 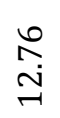 & 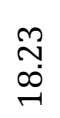 & $\begin{array}{l}\stackrel{L}{\infty} \\
\infty \\
m \\
m\end{array}$ & $\begin{array}{l}\stackrel{L}{\infty} \\
\infty \\
m \\
m\end{array}$ & 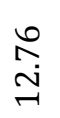 & 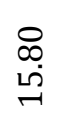 & $\stackrel{\stackrel{\sim}{N}}{\rightarrow}$ & & $\begin{array}{l}\text { Lั? } \\
\text { ஸे }\end{array}$ & $\stackrel{\text { N̦ }}{0}$ & $\begin{array}{l}\text { ț } \\
\infty \\
\infty\end{array}$ & \\
\hline $\begin{array}{l}\text { Ln } \\
\stackrel{2}{N} \\
\text { N }\end{array}$ & $\frac{8}{8}$ & 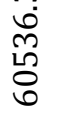 & 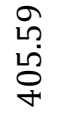 & $\begin{array}{l}\text { ̊े. } \\
\text { oे } \\
\text { ᄋ }\end{array}$ & N̦ & $\begin{array}{l}8 \\
\text { in }\end{array}$ & $\begin{array}{l}\stackrel{0}{\wedge} \\
\stackrel{\rho}{\rho} \\
\stackrel{m}{m}\end{array}$ & 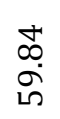 & 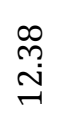 & $\begin{array}{l}\vec{b} \\
\dot{\sigma}\end{array}$ & $\begin{array}{l}\qquad 0 \\
\infty \\
0 \\
\dot{m}\end{array}$ & $\begin{array}{l}\text { Ln } \\
\infty \\
0 \\
\dot{m}\end{array}$ & 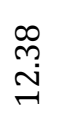 & $\begin{array}{l}m \\
m \\
\stackrel{m}{\sim}\end{array}$ & ํํำ & & \begin{tabular}{l}
0 \\
\multirow{7}{0}{} \\
\multirow{2}{0}{}
\end{tabular} & m. & f̊: & \\
\hline 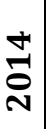 & 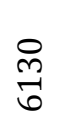 & $\underset{\hat{\overbrace{}}}{\stackrel{N}{N}}$ & $\begin{array}{l}\text { ָै } \\
\stackrel{8}{\circ} \\
\text { mे }\end{array}$ & 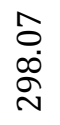 & ㄱ. & $\begin{array}{l}\text { ¿ } \\
\sigma\end{array}$ & $\begin{array}{l}\underset{\sim}{\stackrel{\infty}{*}} \\
\underset{m}{m}\end{array}$ & 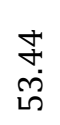 & 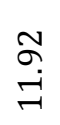 & 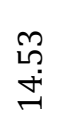 & $\begin{array}{l}\text { oे } \\
\text { ڤे }\end{array}$ & 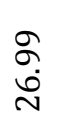 & 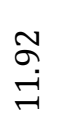 & $\begin{array}{r}\hat{\sim} \\
\stackrel{+}{+}\end{array}$ & $\hat{尺}$ & & $\begin{array}{l}\stackrel{\infty}{N} \\
\stackrel{N}{N}\end{array}$ & $\stackrel{\sharp}{\sharp}$ & $\begin{array}{l}\stackrel{0}{\infty} \\
\sigma^{\circ}\end{array}$ & \\
\hline 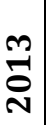 & $\begin{array}{l}\text { : } \\
\text { 내ำ }\end{array}$ & 令 & $\begin{array}{l}\text { Lू } \\
\underset{N}{N} \\
\text { N}\end{array}$ & $\begin{array}{l}\infty \\
\stackrel{\infty}{0} \\
\stackrel{+}{\infty} \\
\stackrel{\sim}{N}\end{array}$ & $\begin{array}{l}\stackrel{L}{\wedge} \\
\infty \\
\stackrel{\infty}{N}\end{array}$ & $\begin{array}{l}8 \\
\text { in } \\
\text { In }\end{array}$ & $\begin{array}{l}m \\
m \\
\infty \\
\stackrel{N}{m}\end{array}$ & $\begin{array}{l}\text { Uु } \\
\dot{F}\end{array}$ & $\stackrel{\substack{m \\
\rightarrow}}{\rightarrow}$ & $\begin{array}{l}\tilde{Z} \\
\stackrel{-}{ت}\end{array}$ & $\begin{array}{l}\stackrel{8}{0} \\
\stackrel{i}{N}\end{array}$ & $\begin{array}{l}\stackrel{8}{0} \\
\stackrel{\text { N }}{ }\end{array}$ & $\stackrel{\substack{m \\
\ddagger}}{\rightarrow}$ & $\stackrel{\circ}{\stackrel{+}{+}}$ & $\begin{array}{l}0 \\
\stackrel{0}{0} \\
\text { in }\end{array}$ & & $\begin{array}{l}\infty \\
0 \\
0 \\
\emptyset\end{array}$ & เे & $\begin{array}{l}\text { 음 } \\
\text { a }\end{array}$ & \\
\hline $\begin{array}{l}\mathfrak{N} \\
\stackrel{B}{N}\end{array}$ & ஓे & \begin{tabular}{l}
$\infty$ \\
0 \\
0 \\
0 \\
\hdashline
\end{tabular} & $\begin{array}{l}\stackrel{m}{n} \\
\underset{\sim}{n}\end{array}$ & $\begin{array}{l}\text { L } \\
\infty \\
\infty \\
\infty \\
\sim \\
\sim\end{array}$ & $\begin{array}{l}0 \\
\stackrel{\sim}{N}\end{array}$ & $\begin{array}{l}\text { \& } \\
\text { Ln }\end{array}$ & $\begin{array}{l}\vec{\sigma} \\
\overrightarrow{-} \\
\vec{m}\end{array}$ & $\stackrel{\sim}{\tilde{y}}$ & $\begin{array}{l}\stackrel{20}{\hat{0}} \\
\stackrel{0}{0}\end{array}$ & $\begin{array}{l}\stackrel{0}{0} \\
\stackrel{0}{0}\end{array}$ & $\begin{array}{l}\hat{\infty} \\
\stackrel{0}{\sigma} \\
\stackrel{-}{-1}\end{array}$ & \begin{tabular}{l}
$\hat{\infty}$ \\
$\infty$ \\
\multirow{\sigma}{*}{}
\end{tabular} & 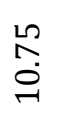 & $\stackrel{\sim}{m}$ & 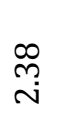 & & $\begin{array}{l}\tilde{\sigma} \\
\stackrel{+}{\sim}\end{array}$ & $\begin{array}{l}0 \\
\stackrel{0}{0}\end{array}$ & ๙ু & \\
\hline$\vec{z}$ & $\stackrel{\text { N }}{\text { f }}$ & $\underset{\stackrel{\sim}{\sim}}{\stackrel{\sim}{N}}$ & $\begin{array}{l}\text { ก๊ } \\
\infty \\
\text { N } \\
\text { nd }\end{array}$ & $\begin{array}{l}\infty \\
\stackrel{0}{0} \\
\stackrel{0}{\circ} \\
\stackrel{1}{N}\end{array}$ & $\begin{array}{l}\text { Nै } \\
\stackrel{\text { L }}{N}\end{array}$ & $\begin{array}{l}\stackrel{8}{0} \\
\stackrel{\leftrightarrow}{N}\end{array}$ & $\begin{array}{l}8 \\
\dot{0} \\
\text { ลे }\end{array}$ & $\begin{array}{l}\text { Nิ } \\
\text { กิ }\end{array}$ & $\begin{array}{l}m \\
0 \\
0\end{array}$ & 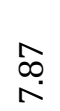 & 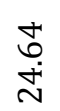 & $\begin{array}{l}\text { Jे } \\
\stackrel{\text { N }}{\text { N }}\end{array}$ & $\begin{array}{l}m \\
0 \\
0\end{array}$ & 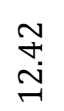 & 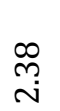 & & $\begin{array}{l}\hat{\infty} \\
\infty \\
\stackrel{\sim}{\sim}\end{array}$ & ه. & $\begin{array}{l}\stackrel{\sigma}{-} \\
\stackrel{-}{6}\end{array}$ & 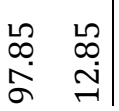 \\
\hline
\end{tabular}


InmHWHWm

Determination of ENPV: The NPV is determined under three different cost scenarios - namely, the pessimistic, the most likely and the optimistic scenario. However, the NPV results obtained under each of the cost scenario does not enable decision-making. To simplify the situation further, in a conservative approach, the HSI managers assigned probability to each of the scenarios. HSI managers believe that the likelihood of optimistic scenario is only $10 \%$; the pessimistic scenario is $55 \%$, while the most likely cost scenario has a probability of $35 \%$. The NPV estimated for each scenario is then reduced to probability based single NPV, which can be referred as ENPV. These calculations are shown in : Table 15 . By changing the probabilities associated with each scenario, the ENPV of the project can be estimated under different conditions. With the conservative approach towards probability of each of the scenarios, the estimated ENPV of the project is estimated to be 2.79 million, which indicates that the project is profitable and can be accepted under the given circumstances.

Table 14: Determination of ENPV

\begin{tabular}{|c|c|c|c|}
\hline Scenario & Probability & NPV & ENPV \\
\hline Optimistic & $10 \%$ & 35.20 & 3.52 \\
\hline Most Likely (Expected) & $35 \%$ & -9.50 & -5.23 \\
\hline Pessimistic & $55 \%$ & 12.85 & 4.50 \\
\hline Total Probability & $100 \%$ & & 2.79 \\
\hline
\end{tabular}

\section{Conclusion}

IP is an asset that forms an inseparable part of a business enterprise and qualifies the definition of an intangible asset under IAS. While the economy transforms into a knowledge economy, valuation of patents and other forms of IP will be crucial. The traditional NPV method (income approach) based on the DCF approach has been used since ages for valuation of equity shares, business enterprise, and intellectual property. However, there are subtle differences while approaching valuation of each of these assets. Despite the fact that the income approach method involves a number of uncertain variables that need to be forecasted over a long period, it is a method that takes into consideration a critical financial parameter - the time value of money, in addition to the commercialization potential of the technology.

One of the approaches to identify the commercialization opportunity is scenario analysis, which involves simulating the investment under different economic scenarios. This tends to take into consideration the uncertainty in future, which the management needs to be aware of. In other words, to incorporate a possibility of an event in the future, the ENPV, which is the Expected Net Present Value, is a better indicator of project profitability instead of the NPV itself. In the case discussed in this paper, the positive ENPV serves as an indicator of the profitability of the project.

However, the ENPV method does not include the managerial flexibility in the analysis, which in fact sets the theme for further research on the commercialization proposal using the Real Options Valuation (ROV) method that enables consideration of managerial flexibility. In addition, in cases where the ENPV is too low or negative, ROV approach can be adopted to incorporate the impact of the economic events during the term of the license. 


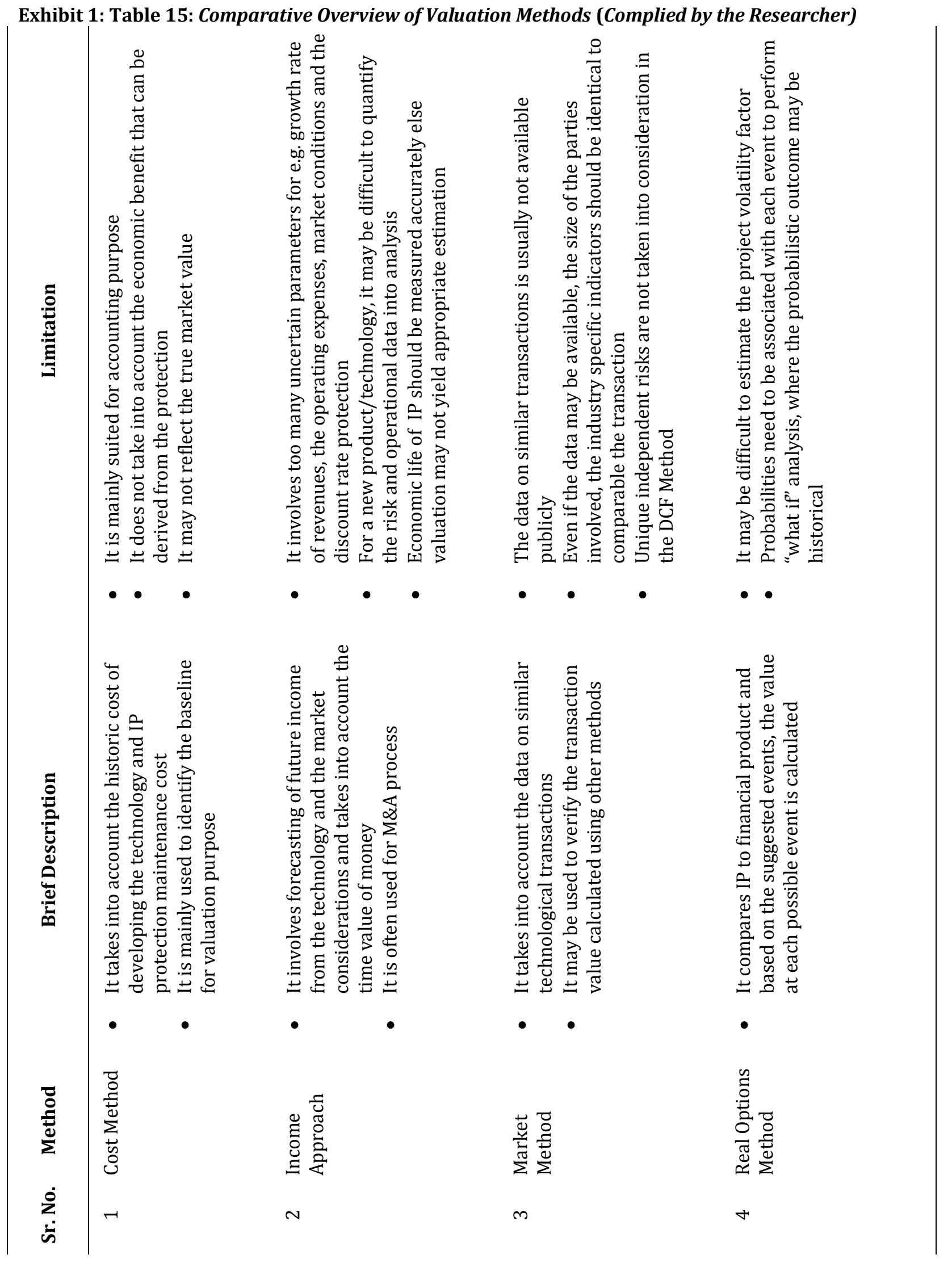




\section{References}

Board of the International Accounting Standards Committee (IASC). International Accounting Standards, Article 38.8

Catherine, J., Holland, D. M., Reed, S. H., Lee, A. I., Kimmel, W. \& Peterson, K. (2007). Intellectual Property: Patents, Trademarks, Copyrights and Trade Secrets, Canada: Entrepreneur Press.

Christos, P. (2009). Edith Penrose's 'The Theory of the Growth of the Firm' Fifty Years Later, Retrieved July 13, 2011 from Munich Personal RePEc Archive, Website: http://mpra.ub.unimuenchen.de/23180/1/MPRA_paper_23180.pdf.

Edith, P., Edith, T. P. \& Christos, P. (2009). The Theory of Growth of Firms, Great Britain: Oxford University Press (Originally Published in 1959).

James, R., McGuigan, R., Charles, M., Frederick, H. \& deB, H. (2007). Managerial Economics: Applications, Strategies, and Tactics, Ohio: Thomson South-Western.

Jeffrey, A. C. (2005). Intangible Assets: Valuation and Economic Benefit, United States of America: John Wiley \& Sons Inc.

Manfred, B., Adolf, K., Ursula, S. \& Karin, I. (1999). Holistic Measurement of Intellectual Capital, OECD International Symposium, Amsterdam.

Norman, C. (2005). The Maximum Achievable Profit Method of Patent Valuation. International Journal of Innovation and Technology Management, World Scientific Publishing Company, 2(2), 135-151.

Oliver, Y. (2006). Applications of Real Options Theory to Technology Management - Major Acceptance Barriers and Successful Removal Strategies, Presented at International Association for Management of Technology, Retrieved from International Association for Management of Technology on July 13, 2011, Website: http://www.iamot.org/conference/index.php/ocs/10/paper/viewFile/1290/567.

Pamela, G. (2004). Intellectual Property Life Estimation Approaches and Methods. In Robert Reilly \& Robert Schweihs (Ed), the Handbook of Business Valuation and Intellectual Property Analysis (421), the McGraw Hill Companies.

Richard, R. (2009). Method 2 - The Rating/Ranking Method and Tool. Valuation and Deal Making of Technology-based Intellectual Property, United States of America: John Wiley \& Sons Inc.

Ross, G. (2002). Valuation and Investment Appraisal, United Kingdom: Financial World Publishing.

Robert, P. (1997). The Valuation of Patents: A Review of Patent Valuation Methods with Consideration of Option Based Methods and the Potential for Further Research, The Said Business School, University of Oxford, Retrieved from Word press on July 13, 2011, Website: http://propriedadeintelectual.files.wordpress.com/2008/04/sessao8c.pdf.

Spruson, D. \& Ferguson, N. (2007). A Practical Guide for Electrical and Electronics Related Industries. Australian Government Initiative.

Subhash, C. \& Vishakha, M. (2010). Disclosure of Intangible Assets in Indian Drugs and Pharmaceutical Industry. The IUP Journal of Accounting Research and Audit Practices, 9 (4), 7-23.

Timothy, M. (2004). Intellectual Property Discount Rates and Capitalization Rates. In Robert Reilly \& Robert Schweihs (Ed), the Handbook of Business Valuation and Intellectual Property Analysis (pp 412), the McGraw Hill Companies.

Warren, D. M. (2010). Value Maps: Valuation Tools That Unlock Business Wealth, United States of America: John Wiley \& Sons.

Weston, A., Donna, P. \& Suchy, C. A. (2005). Fundamentals of Intellectual Property Valuation: A Primer for Identifying and Determining Value, American Bar Association.

World Trade Organization (1995). Agreement on Trade-Related Aspects of Intellectual Property Rights, Part II, Article 33. 